\title{
METODE GRAVITY LOCATION UNTUK OPTIMASI PENENTUAN LOKASI GUDANG PADA JARINGAN DISTRIBUSI DI PT XYZ
}

\section{Gravity Location Method to Optimize the Determination of Warehouse Location On The Distribution Network of PT XYZ}

\author{
Athiyyah Zhafarina'), Adji Candra Kurniawann'), A.A.N. Perwira Redi ${ }^{3)}$, Nanda \\ Ruswandi $\left.i^{*}\right)$ \\ 1,2,4 Departemen Teknik Logistik, Universitas Pertamina, Jakarta, Indonesia \\ ${ }^{3}$ BINUS Graduate Program - Master of Industrial Engineering, Bina Nusantara University, Jakarta, Indonesia 11480
}

\section{ARTICLE INFORMATION}

Article history:

Received: September 09, 20

Revised: January 15, 21

Accepted: February 17, 21

Keywords:

Gravity location model

Facility location problem

Warehouse location problem

Transportation cost optimization

Kata kunci:

Gravity location model

Penentuan Lokasi Fasilitas

Penentuan Lokasi Gudang

Minimasi biaya transportasi

\section{A B S T R A C T}

$X Y Z$ company is a large textile dye companies in Indonesia. To reach existing consumers with lower transportation costs, $X Y Z$ Company plans to add new warehouses. This study provides an analysis using mathematical modeling for the problem of selecting a new facility location for $X Y Z$ company. The purpose of the model used is to provide recommendations for the location of candidate warehouse facilities that will be used as new warehouses. This study uses the gravity location method which is implemented simply with Microsoft Excel software. This method was chosen based on its suitability with the description of the problems XYZ company has. In this study, the data required to determine the location of the best facilities were collected according to the gravity location method procedure. The data collected is data related to consumers from $X Y Z$ companies such as location (latitude, longitude), number of requests, and distance data. The results of managerial analysis related to the old location and the new location for the facilities that will be used by the XYZ company show that the new location is projected to provide transportation cost savings of Rp. 416,910 , - or $21 \%$ per week.

\section{A B S T R A K}

Perusahaan XYZ merupakan perusahaan pewarna tekstil yang cukup besar di Indonesia. Untuk menjangkau konsumen yang sudah ada dengan biaya transportasi yang lebih rendah Perusahaan XYZ berencana melakukan penambahan gudang baru. Penelitian ini memberikan analisa menggunakan pemodelan matematis untuk permasalahan pemilihan lokasi fasilitas baru bagi perusahaan XYZ. Tujuan dari model yang digunakan ini adalah memberikan rekomendasi lokasi kandidat fasilitas gudang yang akan digunakan sebagai gudang baru. Penelitian ini menggunakan metode gravity location yang diimplementasikan secara sederhana dengan perangkat lunak Microsoft Excel. Metode ini dipilih berdasarkan kesesuaiannya dengan deskripsi permasalahan yang dimiliki perusahaan XYZ. Dalam penelitian ini dikumpulkan data yang dibutuhkan untuk menentukan lokasi fasilitas terbaik sesuai dengan prosedur metode gravity location. Data yang dikumpulkan adalah data terkait konsumen dari perusahaan $\mathrm{XYZ}$ seperti lokasi (latitude, longitude), jumlah permintaan, dan data jarak. Hasil analisa manajerial terkait lokasi lama dan lokasi baru untuk fasilitas yang akan digunakan perusahaan XYZ menunjukkan lokasi baru diproyeksikan dapat memberikan penghematan biaya transportasi sebesar Rp. 416.910,- atau sebesar $21 \%$ per minggu nya.
${ }^{*}$ Corresponding Author

Nanda Ruswandi

E-mail:

nandaruswandi.industri@gmail.com
This is an open access article under the $\mathrm{CC}-\mathrm{BY}$ license.

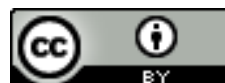




\section{PENDAHULUAN}

Berdasarkan data dari Kementerian Perindustrian, industri tekstil dan pakaian jadi menunjukkan kinerja yang gemilang sepanjang tahun 2019 dengan mencatatkan pertumbuhan sebesar 15,35\%. Capaian tersebut menunjukkan perkembangan yang terus membaik di tengah tekanan kondisi ekonomi global. Pertumbuhan signifikan di sektor industri tekstil dan pakaian jadi ditopang oleh meningkatnya produksi pakaian jadi di sentra-sentra industri [1]. Meskipun pada tahun 2020 nilai ekspor tekstil menunjukkan penurunan yang merupakan akibat wabah COVID-19, sektor ini tetap diharapkan akan mampu kembali bangkit setelah berakhirnya wabah pandemi virus COVID-19.

Pertumbuhan penduduk yang sangat dinamis tiap tahunnya, tentu menyebabkan kebutuhan akan meningkat, salah satunya adalah kebutuhan sandang yang merupakan salah satu kebutuhan pokok manusia. Persaingan bisnis yang ketat dan global termasuk banyaknya produk impor yang masuk membuat perusahaan industri tekstil lokal harus lebih inovatif dan kreatif dalam menciptakan produk, hingga menjaga kepercayaan konsumen terhadap produk mereka. Dorongan terhadap inovasi ini semakin menguat dengan perkembangan teknologi dan ilmu pengetahuan dalam merancang jaringan rantai pasok yang lebih efisien dan efektif dalam memenuhi kebutuhan konsumen. Salah satu strategi dalam perancangan rantai pasok yang efektif dan efisien adalah melakukan pemilihan fasilitas lokasi gudang yang sesuai kebutuhan perusahaan.

Penentuan lokasi fasilitas menggunakan pendekatan pemodelan matematis dan analytics banyak dilakukan pada penelitian terdahulu. Penelitian terkait penentuan lokasi fasilitas bisa dikelompokkan berdasarkan berbagai kategori. Kategori yang umum digunakan misalnya berdasarkan lokasi kandidat fasilitas sudah ditentukan atau belum ditentukan sebelumnya. Berdasarkan fungsi tujuan dari penentuan lokasi fasilitas misalnya minimasi biaya, minimasi jumlah fasiitas, maksimasi area permintaan yang dapat dijangkau, minimasi jangkauan. Kemudian masih banyak lagi kategori yang digunakan, pembaca yang tertarik untuk mendalami topik ini dapat melihat pembahasan pada review yang dilakukan oleh Melo dkk. [2]. Oleh karena itu menentukan model yang tepat harus disesuaikan dengan permasalahaan yang dihadapi perusahaan.

Penelitian terkait penentuan lokasi fasilitas dengan kandidat lokasi fasilitas sudah ditentukan sebelumnya biasanya menggunakan model yang terkait hub location problem [3]. Model matematis terkait hub location memiliki konvensi penamaan yang sesuai dengan fungsi tujuan dan batasan masalah yang dipertimbangkan. Implementasi model matematisnya dapat ditemui di berbagai bidang. Mayoritas penggunaannya tentu terkait penentuan lokasi fasilitas seperti gudang dan pusat distribusi dengan tujuan minimasi biaya [4]. Selain itu ada juga contoh penggunaan model matematis penentuan lokasi pada penentuan lokasi fasilitas pembuangan akhir sampah yang mampu memaksimalkan cakupan area dengan jumlah fasilitas yang terbatas dengan model matematis yang disebut maximum coverage location model [5]. Model yang sama juga dapat digunakan untuk menentukan lokasi parkir untuk fasilitas bike sharing yang belakangan banyak digunakan masyarakat [6].

Penentuan lokasi fasilitas dimana kandidat lokasi fasilitas belum ditentukan sebelumnya sering menggunakan metode gravity location untuk pencarian solusinya. Kebanyakan penggunaan metode gravity location digunakan untuk membantu menentukan letak lokasi gudang dengan tujuan minimasi biaya transportasi [7], [8]. Metode tersebut juga diimplementasikan pada berbagai studi kasus di berbagai perusahaan [9], [10]. Selain aplikasinya pada penentuan lokasi fasilitas gudang, penelitian lain juga menunjukkan implementasi metode gravity location untuk berbagai jenis lokasi fasilitas seperti lokasi perusahaan cabang [11], gudang suku cadang [12], fasilitas daur ulang elektronik [13], dan lokasi lumbung pangan [14]. Dalam penelitianpenelitian tersebut dilaporkan bahwa menggunakan metode gravity location dapat membantu pengambil keputusan dalam menentukan lokasi terutama sebagai arahan awal untuk melakukan survey lebih detail di area lokasi yang disarankan melalui metode gravity location. Berdasarkan pemaparan dari pihak perusahaan $X Y Z$, diperlukan adanya penambahan gudang baru memiliki fokus untuk dapat menjangkau konsumen yang sudah ada dengan biaya transportasi yang lebih rendah.

Penelitian ini kemudian memberikan analisa menggunakan pemodelan matematis untuk 
permasalahan pemilihan lokasi fasilitas baru bagi perusahaan XYZ. Tujuan dari model yang digunakan ini adalah memberikan rekomendasi lokasi kandidat fasilitas gudang yang akan digunakan sebagai gudang baru. Namun demikian, perusahaan $\mathrm{XYZ}$ belum menentukan kandidat-kanditat yang akan dipilih menjadi gudang baru. Selain itu, rekomendasi yang diberikan juga dianalisa dalam tatanan manajerial sehingga dapat lebih realistis sekiranya ingin digunakan dalam pengambilan keputusan. Penelitian ini menggunakan metode center of gravity location atau seringkali disebut metode gravity location. Metode ini digunakan berdasarkan kesesuaian deskripsi permasalahan yang dimiliki perusahaan XYZ. Metode gravity location model memiliki kelebihan dibandingkan metode pemilihan lokasi fasilitas seperti hub locaiton model ( $p$-median, $p$-center, dan covering problem) karena tidak memerlukan kandidat lokasi fasilitas yang ditentukan terlebih dahulu. Metode ini dapat memberikan arahan area lokasi yang dapat meminimasi biaya transportasi untuk pemenuhan permintaan dari pelanggan berdasarkan data historis yang dimiliki. Demikian pula hasil studi literatur menunjukkan metode gravity location telah banyak dilaporkan dan dapat digunakan sebagai cara untuk melakukan pemilihan lokasi fasilitas gudang baru.

Dalam penelitian ini, pertama-tama akan dibahas literatur terkait penggunaan model matematis untuk pemilihan lokasi fasilitas. Berikutnya pada metode penelitian yang digunakan termasuk formulasi matematis dan prosedur dari metode gravity location. Kemudian dilanjutkan dengan hasil dan pembahasan yang berisi deskripsi data yang digunakan dan hasil eksperimen pengolahan data menggunakan metode gravity location. Terakhir kesimpulan dan arah penelitian kedepan.

\section{METODE PENELITIAN}

Perusahaan $X Y Z$ merupakan salah satu perusahaan pewarna tekstil yang cukup besar di Indonesia. Konsumennya tersebar di wilayah pulau Jawa, mulai dari wilayah Tangerang hingga wilayah Jawa Timur. Saat ini, Perusahaan $X Y Z$ memiliki tiga gudang yang berada di wilayah Bekasi, Bandung, dan Solo. Perusahaan XYZ memiliki rencana penambahan gudang untuk melakukan penambahan lokasi gudang pada wilayah area Jabodetabek, Banten, dan Jawa Barat. Hal ini dilakukan berdasarkan pengamatan terhadap trend kebutuhan pewarna tekstil dari pelangggan di area tersebut dan perlunya penambahan kapasitas pada gudang Bekasi.

Berdasarkan penelitian terdahulu [15], peneliti melihat permasalahan pemilihan lokasi fasilitas yang ada di perusahaan XYZ dapat menggunakan pendekatan pencarian solusi dengan metode gravity location. Oleh karena itu dalam penelitian ini metode tersebut diimplementasikan dengan cara yang sederhana sedemikian hingga dapat diinterpretasikan dengan mudah oleh para pengambil keputusan di perusahaan $X Y Z$.

\subsection{Definisi Permasalahan dan Fomulasi Matematis}

Permasalahan penentuan lokasi fasilitas gudang baru pada perusahaan $X Y Z$ dapat didefinisikan dalam pemodelan matematis. Perusahaan $X Y Z$ menginginkan saran terkait lokasi fasilitas gudang baru yang mempertimbangkan total permintaan masing-masing konsumen dan biaya transportasi untuk pemenuhan permintaan tersebut. Penelitian ini menggunakan formulasi model matematis gravity location dari penelitian sebelumnya [4]. Model formulasi matematis untuk metode gravity location dapat dijabarkan sebagai berikut.

Notasi

Indek yang menunjukkan titik

i lokasi konsumen.

Biaya transportasi per unit

atau per kilometer antara

$c_{i} \quad$ kandidat lokasi fasilitas

dengan lokasi konsumen.

Total permintaan yang

$V_{\mathrm{i}} \quad$ dilakukan ke lokasi

konsumen $i$.

Koordinat $x$ dan $y$ untuk $x_{i}$ dan $y_{i} \quad$ lokasi sumber pasokan $i$.

Koordinat $x$ dan $y$ untuk $x_{0 n}$ dan $y_{0 n} \quad$ lokasi kandidat fasilitas pada iterasi $n$.

$\begin{array}{cc}\text { Minimasi } & T C_{n}=\sum_{i} C_{i} V_{i} j_{i} \\ \text { Batasan } & \underset{(i=}{\left.j\left(x_{\text {on }}-x i\right)^{2}+\left(y_{\text {on }}-y_{i}\right)^{2}\right)^{0,5}}\end{array}$ 


$$
\begin{aligned}
& x_{\text {on }}=\sum_{i} \frac{C_{i} V_{i} x_{i}}{J_{i}}\left(\sum_{i} \frac{C_{i} V_{i}}{J_{i}}\right)^{-1} \\
& y_{\text {on }}=\sum_{i} \frac{C_{i} V_{i} y_{i}}{J_{i}}\left(\sum_{i} \frac{C_{i} V_{i}}{J_{i}}\right)^{-1}
\end{aligned}
$$

Fungsi tujuan dari metode gravity location (1) merupakan minimasi total biaya yang berdasarkan biaya transportasi dan jumlah permintaan ke lokasi konsumen. Persamaan (3) dan (4) digunakan untuk menghitung lokasi koordinat kandidat fasilitas yang baru pada iterasi ke- $n$. Kemudian persamaan (2) digunakan untuk menghitung jarak antara lokasi kandidat fasilitas dengan lokasi konsumen. Iterasi dilakukan beberapa kali sampai ditemukan lokasi kandididat yang memiliki nilai fungsi tujuan paling minimum. Prosedur implementasi metode gravity location dibahas berikutnya.

\subsection{Prosedur Metode Gravity Location}

Sebelum menggunakan metode gravity location data-data yang digunakan sebagai parameter masukan perlu disiapkan. Data-data tersebut diantaranya data permintaan dari konsumen, biaya transportasi per unit dari lokasi fasilitas menuju konsumen, dan metode perhitungan jarak dari lokasi kandidat fasilitas ke masingmasing konsumen. Terdapat banyak metode perhitungan jarak diantaranya menggunakan pendekatan euclidean distance, manhattan distance, dan haversine distance. Persamaan (2) menunjukkan formulasi euclidean distance dimana jarak antar dua titik lokasi diasumsikan bisa diperkirakan dengan mengukur yang menghubungkannya. Namun, secara praktek penggunaan euclidean distance bisa digantikan dengan metode perhitungan jarak lainnya yang lebih sesuai dengan kebutuhan di lapangan.

Gambar 1 menjelaskan diagram alir metode gravity location untuk penentuan lokasi fasilitas. Langkah pertama adalah menghitung jarak antara lokasi kandidat fasilitas saat ini ke masing-masing konsumen berdasarkan persamaan (2) atau persamaan lainnya yang dipilih untuk digunakan. Kemudian data jarak tersebut digunakan untuk menghitung koordinat kandidat lokasi fasilitas baru berdasarkan persamaan (3) dan (4). Berikutnya lakukan perhitungan nilai biaya total yang baru yang berdasarkan lokasi kandidat lokasi fasilitas baru. Algoritma akan selesai jika selisi biaya total kandidat yang baru dengan kandidat yang sebelumnya bernilai sangat kecil dalam hal ini disepakati kurang dari 0.001 .

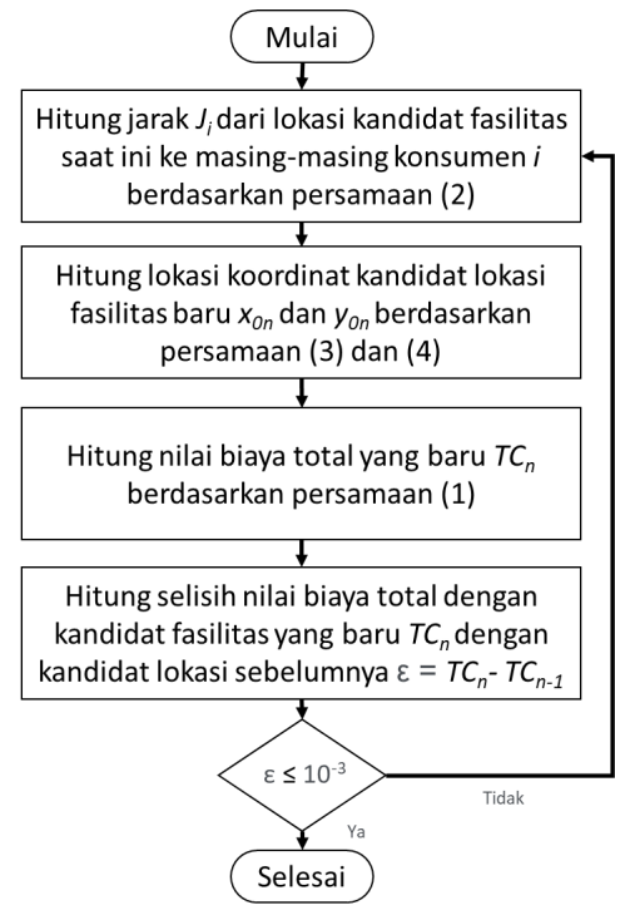

Gambar 1 Diagram Alir Metode Gravity Location Untuk Penentuan Lokasi Fasilitas

\section{HASIL DAN PEMBAHASAN}

\subsection{Pengumpulan Data}

Dalam penelitian ini dikumpulkan data yang dibutuhkan untuk menentukan lokasi fasilitas terbaik sesuai dengan prosedur metode gravity location. Data yang dikumpulkan adalah data terkait konsumen dari perusahaan XYZ seperti lokasi (latitude, longitude), jumlah permintaan, dan data jarak. Data lokasi perusahaan dan konsumen dapat dilihat pada tabel 1. Kolom pertama dan kedua merupakan nomor dan ID dari konsumen. Kolom ketiga dan keempat menunjukkan lokasi konsumen berdasarkan bujur dan lintang yang didapatkan dari alamat konsumen. Kolom terakhir merupakan rata-rata jumlah pengiriman yang dilakukan ke lokasi konsumen tersebut setiap minggu selama dua bulan periode pengumpulan data (Mei sampai Juni 2019). Perusahaan XYZ memiliki armada dengan jumlah kendaraan yang cukup untuk melayani seluruh permintaan dari konsumen tiap minggu. Untuk mempermudah perhitungan biaya operasional kendaraan (BOK), penelitian ini mengacu pada biaya perhitungan BOK per kilometer yang dikeluarkan direktorat perhubungan darat [16]. Penelitian ini memanfaatkan fitur yang disediakan Google Maps untuk perhitungan jarak tempuh antar 
lokasi. Data ini digunakan untuk menggantikan perhitungan jarak berdasarkan persamaan (2) karena memberikan informasi yang lebih akurat dan sesuai dengan keadaan di lapangan.

Gambar 2 memberikan ilustrasi lokasi dan sebaran konsumen dari perusahaan XYZ. Terdapat 15 konsumen yang tersebar mulai dari Kabupaten Serang hingga Kabupaten Karawang. Perusahaan $X Y Z$ sendiri terletak di kota Bekasi. Lokasi kantor sekaligus gudang distribusi saat ini sebenarnya sudah cukup strategis karena dapat menjangkau keseluruhan konsumen dalam waktu yang cukup. Namun, pihak perusahaan memiliki inisiatif untuk mengembangkan bisnis dengan membuka gudang yang lebih luas sedemikian hingga dapat memusatkan kegiatan distribusi pada lokasi gudang baru. Namun demikian, gudang lama tetap akan digunakan sebagai kantor sekaligus pusat administrasi dari perusahaan. Uraian detil mengenai hasil pengolahan data menggunakan metode gravity location model akan dijelaskan pada sub pembahasan berikutnya.

Tabel 1 Data Terkait Konsumen Perusahaan XYZ

\begin{tabular}{ccccc}
\hline No & ID & Lat & Lng & $\mathbf{V}_{\mathbf{i}}$ \\
\hline 0 & Perusahaan XYZ & -6.28583 & 107.09154 & \\
1 & Konsumen 1 & -6.15277 & 106.58160 & 1 \\
2 & Konsumen 2 & -6.29190 & 107.14201 & 1 \\
3 & Konsumen 3 & -6.18843 & 106.81548 & 1 \\
4 & Konsumen 4 & -6.20426 & 106.92937 & 5 \\
5 & Konsumen 5 & -6.40450 & 107.44395 & 1 \\
6 & Konsumen 6 & -6.22164 & 106.36503 & 2 \\
7 & Konsumen 7 & -6.27664 & 107.13584 & 1 \\
8 & Konsumen 8 & -6.19690 & 106.47213 & 1 \\
9 & Konsumen 9 & -6.27757 & 107.13648 & 1 \\
10 & Konsumen 10 & -6.11844 & 106.71267 & 1 \\
11 & Konsumen 11 & -6.18781 & 106.37550 & 1 \\
12 & Konsumen 12 & -6.39425 & 106.93567 & 1 \\
13 & Konsumen 13 & -6.18546 & 106.81487 & 1 \\
14 & Konsumen 14 & -6.28275 & 107.11255 & 1 \\
15 & Konsumen 15 & -6.46861 & 107.39000 & 1 \\
\hline
\end{tabular}

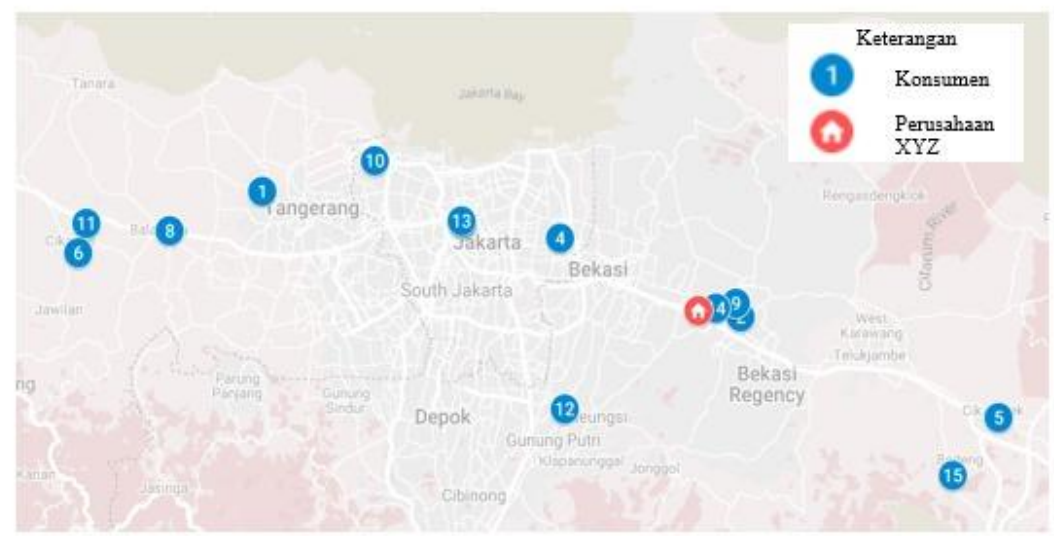

Gambar 2 llustrasi Permasalahan Pemilihan Lokasi Fasilitas Gudang Distribusi di Perusahaan XYZ

\subsection{Hasil Pengolahan Data dengan Metode Gravity Location}

Metode gravity location cukup mudah untuk diimplementasikan tanpa memerlukan kemampuan pemrograman atau kemampuan menggunakan tools yang canggih. Penelitian ini mencontohkan implementasi metode gravity location dengan tabulasi sederhana menggunakan perangkat lunak Microsoft Excel. 
Langkah-langkah yang dilakukan dapat mengikuti diagram alir yang dijelaskan sebelumnya pada sub pembahasan 2.2. Pertama-tama diasumsikan bahwa lokasi kandidat fasilitas awal sama dengan lokasi perusahaan XYZ. Hal ini dilakukan agar metode gravity location tidak memerlukan iterasi yang terlalu banyak untuk menghasilkan kandidat lokasi terbaik berdasarkan prosedur yang harus dilaluinya. Berikutnya akan dibahas lebih detil beserta contoh penerapan metode gravity location.

Tabel 2 menunjukkan contoh perhitungan pada iterasi 1 penentuan lokasi fasilitas dengan metode gravity location. Kolom pertama dan kedua merupakan nomor dan nama yang digunakan sebagai penanda konsumen dan kandidat fasilitas. Kolom-kolom berikutnya digunakan untuk membantu perhitungan pada persamaan (1), (2), (3), dan (4). Penjelasan terkait masing-masing kolom akan dilakukan berikutnya bersamaan dengan langkah-langkah dalam metode gravity locatin. Langkah pertama yang dilakukan adalah menghitung jarak antara lokasi kandidat fasilitas saat ini dengan masingmasing konsumen $\left(J_{i}\right)$. Kolom 3 pada tabel 2 menunjukkan data $\mathrm{Ji}$ yang dihasilkan menggunakan fitur pencarian jarak antara dua lokasi di fitur google maps. Kemudian, dari data jarak tersebut, langkah selanjutnya adalah menghitung lokasi koordinat kandidat fasilitas yang baru menggunakan persamaan (3) dan (4). Perhitungan ini dilakukan dengan membagi total nilai pada kolom 4 dengan total nilai pada kolom 6 untuk mendapatkan koordinat $c$ yang baru. Untuk nilai koordinat yon yang baru didapatkan dengan membagi total nilai pada kolom 5 dengan total nilai pada kolom 6 . Dalam contoh ini, iterasi 1 , didapatkan nilai $\mathrm{x}_{01}$ dan $\mathrm{y}_{01}$ adalah --6.26709 dam 107.04384. Kolom terakhir digunakan untuk menghitung nilai total biaya (TC) pada iterasi saat ini yaitu iterasi 1 . Penting diketahui bahwa nilai TC yang diperoleh pada tiap iterasi, berasosiasi dengan koordinat kandidat fasilitas pada iterasi sebelumnya. Contohnya pada iterasi 1 , maka total biaya sebesar Rp. 2.018.790 merupakan total biaya ketika lokasi fasilitas pada koordinat awal yaitu $x_{0}$ adalah -6.28583 dan yon adalah 107.09154. Oleh karena itu pengecekan nilai selisih total biaya $\varepsilon=T C_{n^{-}} T C_{n-1}$ hanya dilakukan ketika $n$ lebih dari satu.

Metode gravity location dilakukan sesuai prosedur yang dijelaskan sebelumnya akan memerlukan beberapa kali iterasi sampai memperoleh hasil yang konvergen dengan indikator nilai total biaya tidak memiliki selisih yang besar dari satu iterasi dengan iterasi sebelumnya $\left(\varepsilon \leq 10^{-3}\right)$. Dalam kasus penentuan lokasi fasilitas untuk perusahaan $X Y Z$, ilustrasi total biaya pada tiap iterasi dapat dilihat pada gambar 3. Gambar tersebut menunjukkan bahwa total biaya yang dihasilkan pada lokasi fasilitas yang dipilih di iterasi 1 mengalami penurunan yang cukup besar pada iterasi 2. Hal tersebut juga terjadi pada iterasi 3, 4, dan 5. Namun, pada iterasi 6 dan iterasi berikutnya hampir tidak terjadi penurunan total biaya yang cukup signifikan. Sampai akhirnya penurunan biaya sangat kecil terjadi pada iterasi $10\left(\varepsilon \leq 10^{-3}\right)$ sehingga algoritma dapat diselesaikan. Tabel 3 menunjukkan contoh perhitungan pada iterasi 5 untuk penentuan lokasi fasilitas dengan metode gravity location. Peneliti memilih menggunakan hasil dari iterasi ini sebagai hasil dari metode gravity location karena hasil dari iterasi berikutnya tidak terlalu berbeda secara signifikan. Penggunaan metode gravity location untuk penentuan lokasi fasilitas pada perusahaan XYZ menghasilkan lokasi fasilitas yang terbaik yang dihasilkan metode ini terletak pada Xon adalah -6.20866 dan yon adalah 106.92762 dengan total biaya adalah Rp. 1.601.880.

Tabel 2 Contoh Perhitungan pada Iterasi 1 Penentuan Lokasi Fasilitas dengan Metode Gravity Location

\begin{tabular}{|c|c|c|c|c|c|c|}
\hline No & Nama & $\mathbf{J}_{\mathbf{i}}$ & $\mathrm{C}_{\mathrm{i}} * \mathbf{V}_{\mathrm{i}} * \mathbf{X}_{\mathrm{i}} / \mathbf{J}_{\mathrm{i}}$ & $\mathrm{C}_{\mathrm{i}}^{*} \mathrm{~V}_{\mathrm{i}} * \mathrm{Y}_{\mathrm{i}} / \mathrm{J}$ & $\mathrm{C}_{\mathrm{i}} * \mathrm{~V}_{\mathrm{i}} / \mathrm{J}_{\mathrm{i}}$ & $\mathbf{C}_{\mathrm{i}} * \mathbf{V}_{\mathrm{i}}^{*} \mathbf{J}_{\mathrm{i}}$ \\
\hline 0 & Kandidat Fasilitas & & & & & \\
\hline 1 & Konsumen 1 & 56.9 & -324.399 & 5619.417 & 52.72408 & 170700 \\
\hline 2 & Konsumen 2 & 7.07 & -2669.83 & 45463.37 & 424.3281 & 21210 \\
\hline 3 & Konsumen 3 & 30.89 & -601.013 & 10373.79 & 97.11881 & 92670 \\
\hline 4 & Konsumen 4 & 18.26 & -5096.6 & 87839.02 & 821.4677 & 273900 \\
\hline 5 & Konsumen 5 & 39.35 & -488.272 & 8191.406 & 76.23888 & 118050 \\
\hline 6 & Konsumen 6 & 80.84 & -461.775 & 7894.485 & 74.22068 & 485040 \\
\hline 7 & Konsumen 7 & 4.9 & -3842.84 & 65593.37 & 612.2449 & 14700 \\
\hline 8 & Konsumen 8 & 68.97 & -269.548 & 4631.236 & 43.49717 & 206910 \\
\hline 9 & Konsumen 9 & 4.97 & -3789.28 & 64669.91 & 603.6217 & 14910 \\
\hline 10 & Konsumen 10 & 42.51 & -431.788 & 7530.887 & 70.57163 & 127530 \\
\hline 11 & Konsumen 11 & 79.71 & -232.887 & 4003.594 & 37.63643 & 239130 \\
\hline 12 & Konsumen 12 & 17.72 & -1082.55 & 18104.23 & 169.3002 & 53160 \\
\hline 13 & Konsumen 13 & 30.97 & -599.173 & 10346.94 & 96.86794 & 92910 \\
\hline
\end{tabular}


Jurnal Manajemen Industri dan Logistik Vol. 05 No. 01 Mei, 2021, 31-41

\begin{tabular}{lllllll}
\hline $\mathbf{N o}$ & Nama & $\mathbf{J}_{\mathbf{i}}$ & $\mathbf{C}_{\mathbf{i}}^{*} \mathbf{V}_{\mathbf{i}}^{*} \mathbf{X}_{\mathbf{i}} / \mathbf{J}_{\mathbf{i}}$ & $\mathbf{C}_{\mathbf{i}}^{*} \mathbf{V}_{\mathbf{i}}^{*} \mathbf{Y}_{\mathbf{i}} / \mathbf{J}$ & $\mathbf{C}_{\mathbf{i}} * \mathbf{V}_{\mathbf{i}} / \mathbf{J}_{\mathbf{i}}$ & $\mathbf{C}_{\mathbf{i}}^{*} \mathbf{V}_{\mathbf{i}}^{*} \mathbf{J}_{\mathbf{i}}$ \\
\hline 14 & Konsumen 14 & 2.3 & -8194.89 & 139712 & 1304.348 & 6900 \\
15 & Konsumen 15 & 33.69 & -576.012 & 9562.778 & 89.0472 & 101070 \\
& Total & & -28660.9 & 489536.4 & 4573.233 & 2018790 \\
\hline
\end{tabular}

Tabel 3 Contoh Perhitungan pada Iterasi 5 Penentuan Lokasi Fasilitas dengan Metode Gravity Location

\begin{tabular}{|c|c|c|c|c|c|c|}
\hline No & Nama & $\mathbf{J}_{\mathbf{i}}$ & $\mathbf{C}_{\mathrm{i}} * \mathbf{V}_{\mathrm{i}} * \mathbf{X}_{\mathrm{i}} / \mathbf{J}_{\mathrm{i}}$ & $\mathbf{C}_{\mathrm{i}} * \mathbf{V}_{\mathrm{i}} * \mathbf{Y}_{\mathrm{i}} / \mathrm{J}$ & $\mathbf{C}_{\mathrm{i}} * \mathbf{V}_{\mathrm{i}} / \mathbf{J}_{\mathrm{i}}$ & $\mathbf{C}_{\mathrm{i}} * \mathrm{~V}_{\mathrm{i}} * \mathrm{~J}_{\mathrm{i}}$ \\
\hline 0 & Kandidat Fasilitas & & & & & \\
\hline 1 & Konsumen 1 & 38.39 & -480.8106 & 8328.857 & 78.14535 & 115170 \\
\hline 2 & Konsumen 2 & 24.1 & -783.22432 & 13337.18 & 124.4813 & 72300 \\
\hline 3 & Konsumen 3 & 12.36 & -1502.0464 & 25926.09 & 242.7184 & 37080 \\
\hline 4 & Konsumen 4 & 0.5 & -186127.86 & 3207881 & 30000 & 7500 \\
\hline 5 & Konsumen 5 & 57.88 & -331.95415 & 5568.968 & 51.83138 & 173640 \\
\hline 6 & Konsumen 6 & 62.42 & -598.04322 & 10224.13 & 96.12304 & 374520 \\
\hline 7 & Konsumen 7 & 23.37 & -805.7303 & 13753 & 128.3697 & 70110 \\
\hline 8 & Konsumen 8 & 50.51 & -368.05967 & 6323.825 & 59.39418 & 151530 \\
\hline 9 & Konsumen 9 & 23.45 & -803.10102 & 13706.16 & 127.9318 & 70350 \\
\hline 10 & Konsumen 10 & 23.97 & -765.76183 & 13355.78 & 125.1564 & 71910 \\
\hline 11 & Konsumen 11 & 61.26 & -303.02674 & 5209.378 & 48.9716 & 183780 \\
\hline 12 & Konsumen 12 & 5.87 & -3267.9322 & 54651.96 & 511.0733 & 17610 \\
\hline 13 & Konsumen 13 & 12.44 & -1491.6714 & 25759.21 & 241.1576 & 37320 \\
\hline 14 & Konsumen 14 & 20.81 & -905.73027 & 15441.5 & 144.1615 & 62430 \\
\hline \multirow[t]{2}{*}{15} & Konsumen 15 & 52.21 & -371.68805 & 6170.657 & 57.46026 & 156630 \\
\hline & Total & & -198906.64 & 3425638 & 32036.98 & 1601880 \\
\hline
\end{tabular}

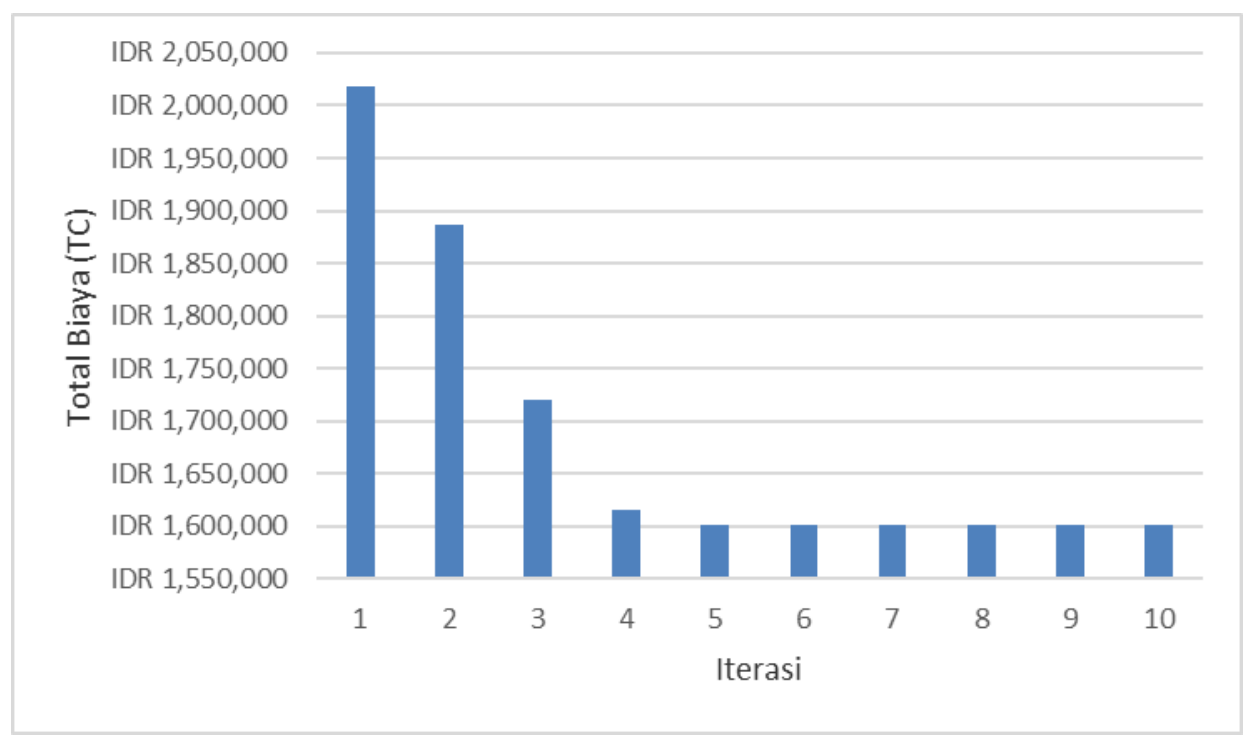

Gambar 3 llustrasi Total Biaya pada Tiap Iterasi Menggunakan Metode Gravity Location

\subsection{Diskusi dan Pembahasan}

Gambar 4 memberikan ilustrasi perbandingan jaringan distribusi menggunakan lokasi fasilitas lama dengan lokasi fasilitas baru yang dipilih menggunakan metode gravity location. Ilustrasi tersebut menggambarkan bahwa lokasi baru yang terpilih memiliki kecondongan berata pada pusat gravity dari keseluruhan konsumen dimana faktor-faktor yang menjadi perhitungan diantaranya adalah jumlah permintaan dan biaya transportasi.
Meskipun lokasi fasilitas yang baru merupakan lokasi yang terbaik beradasarkan metode gravity location, lokasi tersebut tidak serta-merta merupakan lokasi yang akan digunakan oleh perusahaan kedepannya. Seperti disebutkan sebelumnya, metode gravity location merupakan metode sederhana yang dapat digunakan dalam mempertimbangkan keputusan yang akan diambil. Lebih lanjut, hasil lokasi yang disarankan dengan metode gravity location tetap perlu mempertimbangkan faktor-faktor 
lainnya seperti biaya operasional, biaya investasi, biaya tenaga kerja, dan sebagainya.

Hasil dari penelitian ini selanjutnya diajukan bersama dan dibahas kepada para manajer di perusahaan XYZ. Tabel 4 menunjukkan ringkasan dari hasil analisa manajerial terkait lokasi lama dan lokasi baru untuk fasilitas yang akan digunakan perusahaan XYZ. Dari perspektif biaya, lokasi baru diproyeksikan dapat memberikan penghematan biaya transportasi sebesar Rp. 416.910,- atau sebesar $21 \%$ per minggu nya. Lebih jauh lagi, pembangunan fasilitas baru membuka peluang yang lebih besar untuk menangkap pasar baru di daerah kota Jakarta dan wilayah bagian barat seperti Tangerang dan Banten. Namun, pembangunan fasilitas baru tidak serta merta pasti menguntungkan, karena biaya investasi yang tidak kecil perlu diperhitungkan dengan lebih detil. Selain itu, perlu dianalisa lebih lanjut terkait ketersediaan lahan pada lokasi yang didapatkan melalui metode gravity location. Terlepas dari hal tersebut, saat ini perusaahaan $X Y Z$ memang sedang mempertimbangkan penambahan gudang untuk memperbesar kapasitas penyimpanan dan jangkauan konsumen.

Tabel 4 Analisa Manajerial Terkait Lokasi Lama dan Lokasi Baru untuk Fasilitas yang akan digunakan Perusahaan XYZ

\begin{tabular}{|c|c|c|}
\hline & Lokasi Lama & Lokasi Baru \\
\hline Koordinat & $(-6.28583,107.09154)$ & $(-6.20866,106.92762)$ \\
\hline Total Biaya Transportasi & Rp. 2.018.790,-- & Rp. 1.601.880,- \\
\hline Wilayah & Bekasi & Jakarta Timur \\
\hline Kelebihan & $\begin{array}{l}\text { Tidak perlu investasi } \\
\text { lebih pembangunan } \\
\text { fasilitas baru }\end{array}$ & $\begin{array}{l}\text { Peluang menangkap } \\
\text { pasar daerah kota } \\
\text { Jakarta dan wilayah } \\
\text { bagian barat seperti } \\
\text { Tangerang dan Banten }\end{array}$ \\
\hline Kekurangan & $\begin{array}{l}\text { Gudang saat ini } \\
\text { memerlukan } \\
\text { penambahan } \\
\text { kapasitas }\end{array}$ & $\begin{array}{l}\text { Perlu dianalisa lebih } \\
\text { lanjut ketersediaan } \\
\text { lahan di daerah yang } \\
\text { disarankan }\end{array}$ \\
\hline
\end{tabular}

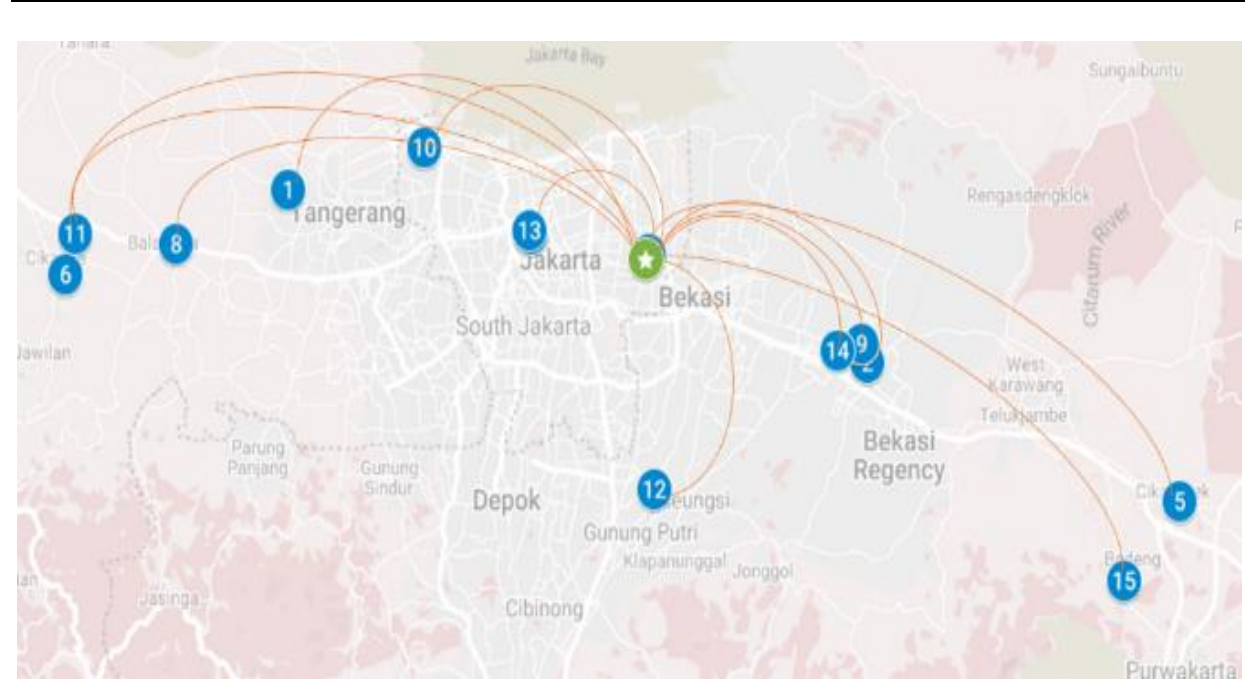

(a) 


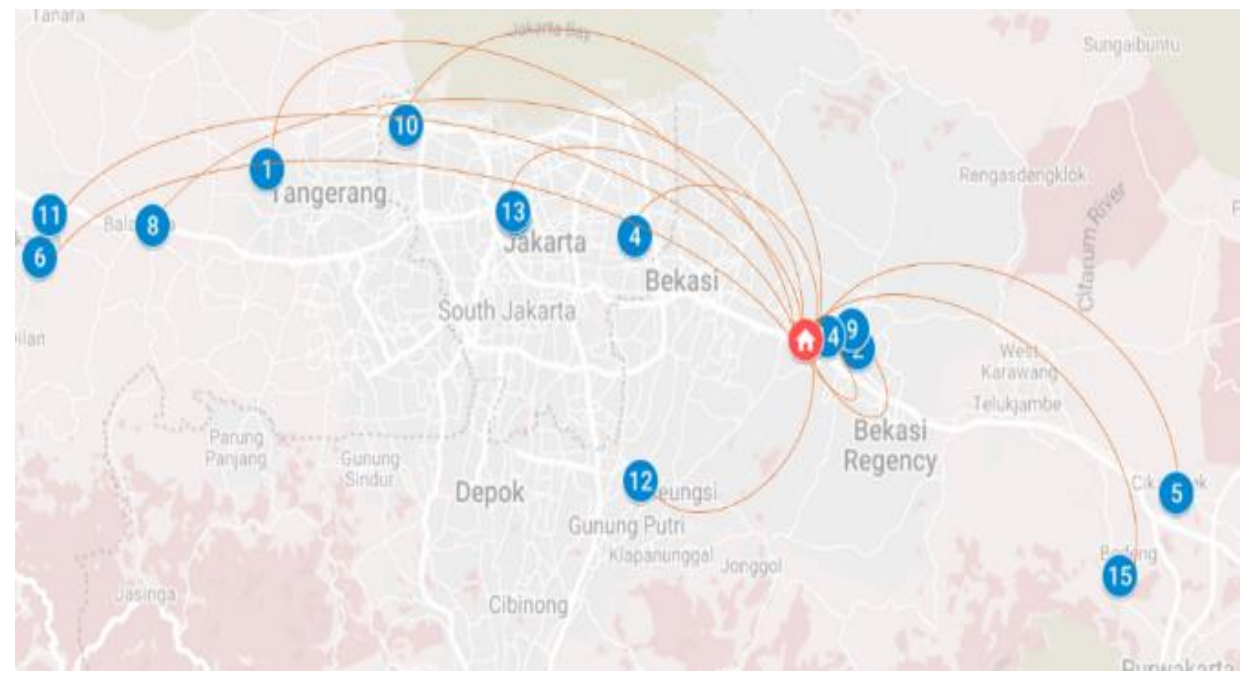

(b)

Gambar 4 llustrasi Lokasi Fasilitas yang Terpilih Melalui Metode Gravity Location (a) dan Lokasi Fasilitas Awal (b)

\section{KESIMPULAN}

Penelitian ini membahas permasalahan pemilihan lokasi fasilitas gudang distribusi baru pada sebuah perusahaan $\mathrm{XYZ}$ yang merupakan perusahaan produsen tekstil. Pendekatan metode gravity location model digunakan untuk membantu pengambilan keputusan dalam pemilihan lokasi fasilitas gudang. Metode tersebut dipilih karena dapat mempertimbangkan lokasi konsumen, jarak, biaya transportasi, dan jumlah permintaan konsumen dalam pemilihan lokasi fasilitas gudang baru. Penelitian ini mengimplentasikan metode tersebut menggunakan software Microsoft Excel. Hasil dari metode gravity location model memperlihatkan bahwa lokasi gudang baru yang menjadi kandidat terpilih terletak di daerah Jakarta Timur. Lokasi gudang baru ini diproyeksikan dapat menghemat biaya transportasi sebesar 21 persen setiap mi2nggunya dengan asumsi pola permintaan yang ada saat ini. Lebih lanjut, hasil penelitian juga telah di diskusikan dengan pihak perusahaan $\mathrm{XYZ}$ sehingga dapat disimpulkan bahwa metode yang digunakan dapat memberikan saran dan pertimbangan yang baik bagi pengambil keputusan di perusahaan $\mathrm{XYZ}$.

Implikasi dari hasil penelitian ini dapat dilihat melalui sudut pandang manajerial dan teoritis. Secara manajerial, hasil penelitian ini dapat dijadikan bahan pertimbangan bagi para pengambil keputusan seperti pempinan dan para manajer untuk mempertimbangkan lokasi fasilitas gudang baru. Namun karena keterbatasan kedalaman analisa yang dapat dilakukan dengan gravity location model maka perlu dilakukan analisa lebih lanjut. Pertimbangan ini juga menjadi implikasi penelitian secara teoritis. Penelitian ini menunjukkan bahwa model gravity location model dapat digunakan untuk membantu analisa pemilihan lokasi fasilitas. Namun, penelitian ini sebaiknya dikembangkan lebih detail dengan mempertimbangkan asumsi di lapangan yang lebih kompleks.

Penelitian ini menggunakan banyak asumsi yang menyederhanakan permasalahan sebenarnya yang jauh lebih kompleks. Beberapa contoh hal yang bisa dikembangkan misalnya penggunaan metode yang mempertimbangkan beberapa kandidat lokasi yang sudah tersedia menggunakan model hub location problem. Selain itu analisa input dari para expert terkait lokasi yang sudah ada berdasarkan berbagai kriteria (multi criteria decision making) juga bisa digunakan. Oleh karena itu, penelitian kedepan dapat mempertimbangkan penambahan faktor-faktor pengambilan keputusan yang lebih kompleks yang terjadi di lapangan.

\section{DAFTAR PUSTAKA}

[1] B. Cahyadi and B. Aulia, "Penentuan Titik Pusat Warehouse dan Sistem Distribusi Portland Composite Cement di Wilayah Wonogiri," Pros. Semnastek, 2018. 
[2] M. T. Melo, S. Nickel, and F. SaldanhaDa-Gama, "Facility location and supply chain management--A review," Eur. J. Oper. Res., vol. 196, no. 2, pp. 401-412, 2009.

[3] H. Mokhtar, A. A. N. P. Redi, M. Krishnamoorthy, and A. T. Ernst, "An intermodal hub location problem for container distribution in Indonesia," Comput. Oper. Res., vol. 104, 2019, doi: 10.1016/j.cor.2018.08.012.

[4] R. A. Fadhil, E. G. Prabowo, and A. A. N. $P$. Redi, "penentuan lokasi distribution center dengan metode $\mathrm{p}$-median di pt pertamina ep," J. Manaj. Ind. dan Logistik, vol. 4, no. 1, pp. 1-9, 2020.

[5] H. S. Amarilies, A. A. N. P. Redi, I. Mufidah, and R. Nadlifatin, "Greedy Heuristics for the Maximum Covering Location Problem: A case study of Optimal Trashcan Location in Kampung Cipare--Tenjo--West Java," in IOP Conference Series: Materials Science and Engineering, 2020, vol. 847, no. 1, p. 12007.

[6] H. S. Amarilies, A. P. Kamil, H. F. Adzkia, and A. A. N. P. Redi, "Maximum Coverage Distance Problem for Dockless Bike Sharing System: A Case Study of the Dockless Bike Sharing System in Jakarta," in Proceedings of the 2020 the 3rd International Conference on Computers in Management and Business, 2020, pp. 306-309.

[7] M. R. Iqbal, I. Hasan, and A. S. Gusmon, "Penentuan Letak Gudang Untuk Meminimkan Biaya Transportasi Dengan Pendekatan Center Of Gravity," J. Manaj. Ind. dan Logistik, vol. 4, no. 1, pp. 67-74, 2020.

[8] E. Adriantantri, Y. A. Pranoto, and T. Priyasmanu, "Aplikasi Penentuan Lokasi Gudang Distribusi Air Mineral Menggunakan Gravity Location Model," J. Teknol. Inf., vol. 6, no. 2, 2015.

[9] Y. Firmansyah and others, "Penentuan Lokasi External Warehouse Dengan Menggunakan Metode Center Of Gravity (Studi Kasus Di Pt. Rpz Surabaya)," J. Manaj. Ind. dan Logistik, 2020.

[10] A. A. Prasetyo, W. Setiafindari, and A. Alfandianto, "Perancangan Tata Letak Bahan Baku Dengan Metode Gravity Location Model (GIm) Di Pt Pertani
(Persero) Cabang DI Yogyakarta," J. Disprotek, vol. 9, no. 1, 2018.

[11] E. W. Yunitasari, "Metode Gravity Location Models Dalam Penentuan Lokasi Cabang Yang Optimal Di PT. ABC," Tekinfo J. Ilm. Tek. Ind. dan Inf., vol. 3, no. 2, pp. 75-82, 2015.

[12] A. Syam and H. H. P. Muh'amat Arifin, "Determining The Optimal Location of Central Spare Part Warehouse for The Leading Taxi Company in Indonesia."

[13] E. Fatma, "Reverse logistic location problem for electrical and electronics equipment waste treatment facility," IPTEK J. Proc. Ser., no. 3, pp. 24-29, 2018.

[14] A. U. T. Ama, E. Sediyono, and A. Setiawan, "Rekayasa Algoritma Gravity Location Models Untuk Penentuan Lokasi Lumbung Pangan Masyarakat Kabupaten Minahasa Tenggara," J. Tek. Inform. dan Sist. Inf., vol. 1, no. 3, 2015.

[15] I. N. Pujawan, "Handout Kuliah Manajemen Logistik: Introduction to Supply Chain Management," Tek. Ind. Inst. Teknol. Sepuluh Nopember, Surabaya, 2002.

[16] J. H. Frans, Y. A. Messah, and N. T. Issu, "Kajian Tarif Angkutan Umum Berdasarkan Biaya Operasional Kendaraan (Bok), Ability To Pay (Atp) Dan Willingness To Pay (Wtp) Di Kabupaten Tts," J. Tek. Sipil, vol. 5, no. 2, pp. 185-198, 2016.

\section{Biografi Penulis}

\section{Athiyyah Zhafarina}

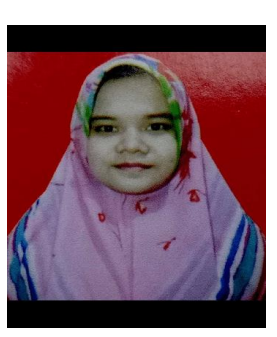

Lahir di Bekasi, 10 Januari 1999, saat ini mahasiswi tingkat akhir program studi Teknik Logistik Universitas Pertamina. Penulis pernah menjadi anggota Himpunan Mahasiswa Teknik Logistik Universitas Pertamina pada tahun 2017-2018 dan menjabat sebagai staf Divisi Pendidikan dan Keilmuan. Penulis juga pernah menjadi asisten laboratorium Statistika dan Probabilitas pada tahun 2018 serta menjadi asisten mata kuliah Manajemen Rantai Pasok pada tahun 2019. 


\section{Adji Candra Kurniawan}

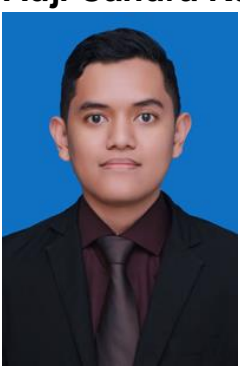

Merupakan dosen tetap di Jurusan Teknik Logistik Universitas Pertamina memperoleh gelar Strata $1 \mathrm{di}$ bidang Teknik Industri di Univ Brawijaya dan memperoleh gelar Strata 2 Pada bidang Logistik dan Rantai Pasok di Nopember Intitut Teknologi Sepuluh

\section{Anak Agung Ngurah Perwira Redi}

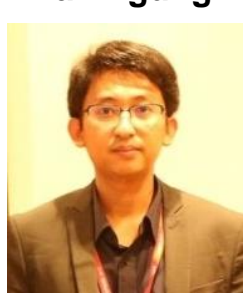

Dr. Redi adalah dosen tetap Magister Teknik Industri, Universitas Bina Nusantara, Sebelumnya merupakan dosen di Jurusan Teknik Logistik Univ. Pertamina.

Berpengalaman sebagai Research Fellow di Monash University, Australia. Memperoleh gelar S2 dan S3 di National Taiwan University of Science and Technology (NTUST).

\section{Nanda Ruswandi}

Merupakan Asisten
Laboratorium/Laboran
jurusan Teknik Logistik
Universitas Pertamina.
Memperoleh gelar Strata 1 di
bidang Teknik Industri
$\begin{aligned} & \text { Universitas } \\ & \text { Padang. }\end{aligned}$

